\title{
KEMAMPUAN INTERAKSISOSIAL SISWA USIA 10-12 TAHUN DIUNGARAN
}

\author{
Abdul Wakhid ${ }^{1}$, Nila Sari Andriani ${ }^{1}$, Mona Saparwati ${ }^{1}$ \\ ${ }^{1}$ Fakultas Keperawatan, UniversitasNgudiWaluyo \\ abdul.wakhid2010@gmail.com
}

\begin{abstract}
ABSTRAK
Ketrampilan social pada anak merupakan kemampuan sosial yang perlu dilatihkan sejak dini, sehingga perkembangan psikososial anak menjadi optimal dan dapat menjalankan tugasnya dengan baik. Tujuan penelitian ini adalah untuk mengetahui gambaran kemampuan interaksi social siswa usia 10-12 Tahun di Ungaran. Desain penelitian ini deskriptif analitik dengan pendekatan survei. Populasi penelitian ini adalah siswa usia 10-12 tahun diUngaran, yaitu sebanyak 117 siswa dengan sampel adalah 91 siswa menggunakan teknik proportional random sampling. Alat pengambilan data menggunakan kuesioner. Analisis data yang digunakan distribusi frekuensi. Hasil penelitian menunjukkan kemampuan interaksi sosial siswa usia 10-12 tahun sebagain besar kategori sedang $(60,4 \%)$. Sebaiknya anak sekolah usia 10-12 tahun meningkatkan kemampuan interaksi social mereka diantaranya dengan meningkatkan rasa saling menghormati dan menghargai sehingga proses belajar dapat berjalan dengan baik.
\end{abstract}

Kata kunci: Interaksi sosial, siswausia 10-12 tahun

\section{DESCRIBE SOCIAL INTERACTION CAPABILITIES OF STUDENTS AGED 10-12 YEARS OLD IN UNGARAN.}

\begin{abstract}
Social skills in children are social abilities that need to be trained early, so that children's psychosocial development becomes optimal and can carry out their duties well. The purpose of this study was to describe social interaction capabilities of students aged 10-12 years old in Ungaran. The study design was descriptive analytic with survey approach. This study population was the students aged 10-12 years old in Elementary School 04 Sidomulyo Ungaran, as many as 117 students where the samples were 91 students using proportional random sampling technique. Data collecting tool used questionnaires. Analysis data used the frequency distribution. The results showed that social interaction skills of students aged 10-12 years old were the majority of them in the middle category (60.4\%). We recommend that school children aged 10-12 should improve their social interaction skills such as by increasing mutual respect and appreciating so that the learning process can run well.
\end{abstract}

Keywords: Social interaction capabilities, students aged 10-12 years old.

\section{PENDAHULUAN}

Anak sekolah dasar dalam setiap aktivitas di sekolah, selalu menjalin interaksi baik dengan temannya, gurunya, maupun kepada manusia lain di lingkungan sekolah. Interaksi sosial anak sekolah dasar ini bermacam-macam, mulai dari imitasi yaitu anak sekolah dasar meniru apa yang diperbuat oleh gurunya misalnya, guru menjabat tangan kepala sekolah ketika bertemu. Anak SD ini juga mencontoh perilaku yang dilakukan oleh guru terebut. Mereka menjabat tangan gurunya ketika datang ataupun ketika pulang, lalu identifikasi yang dilakukan oleh anak sekolah dasar. Mereka meniru aktor-aktor yang diperankan di televisi, misalnya Power Ranger, mereka bermain seperti aktor yang mereka lihat di televisi (Sejiwa, 2008).
Berdasarkan hasil studi pendahuluan yang dilakukan oleh peneliti pada bulan Oktober 2016 di Kabupaten Semarang, diperoleh data sekolah jumlah siswa sebanyak 240 siswa dimana jumlah siswa laki-laki sebanyak 115 siswa dan perempuan 125 siswa. Hasil studi pendahuluan yang dilakukan di Kabupaten Semarang dengan melakukan pengumpulan data terkait dengan interaksi sosial terhadap 10 orang siswa diperoleh enam siswa $(60,0 \%)$ mempunyai interaksi sosial kategori burukdanempat siswa $(40,0 \%)$ mempunyai interaksi sosial kategori tinggi. Hal tersebut menunjukkan bahwa sebagian besar siswa mempunyai interaksi sosial mereka rendah. Tujuan penelitian ini untuk mengetahui gambaran kemampuan interaksi sosial siswa usia 10-12 tahun di Ungaran. 


\section{METODE}

Penelitian ini besifat deskriptif analitik yang bertujuan untuk mengungkapkan gambaran variabel kemampuan interkasi sosial siswa sekolah dasar usia 10-12 tahun.Pendekatan surveidilakukandenganmelakukanpengamatansatu kali terhadap variable yang diteliti. Penelitian ini dilaksanakan tanggal 10 Januari 2017 kepada siswa sekolah dasar usia 10-12 tahun di Ungaran. Populasi penelitian ini, yaitu sebanyak 117 siswa usia 10-12 tahun di Ungaran. Metode pengambilan sampel dalam penelitian ini adalah dengan cara proportional random sampling dengan menggunakan 91 responden. Penentuan sampel untuk masing-masing tingkatan dilakukan dengan cara penunjukkan dengan menggunakan teknik lotrey yaitu secara acak berdasarkan daftar nama siswa dari tiap kelas dengan memperhatikan proporsi pada masing-masing tingkatan kelas, yang diperoleh dengan cara undian.

Alat pengumpul data kemampuan interaksi sosial, terdiri dari indikator kerjasama, akomodasi, asimilasi, persaingan dan pertikaian sejumlah 11 butir pertenyaan (r 0,742-0,978) dengan nilai alpha Cronbach 0,947. Instrument terdiri dari pilihan jawaban ya dan tidak. Pengumpulan data dilakukan dengan cara peneliti meminta surat ijin kepada Dekan Fakultas Keperawatan Universitas Ngudi Waluyo sebagai pengantar yang ditujukan kepada Kepala Sekolah Dasar.Setelah peneliti mendapat ijin penelitian, peneliti melakukan identifikasi data calon responden untuk menentukan jumlah populasi dan sampel yang diteliti yaitu jumlah siswa kelas 4,5 dan 6 berdasarkan absensi kelas, selanjutnya menghitung jumlah sampel yang dibutuhkan, sampel untuk masing-masing kelas dan menentukan teknik sampling yang digunakan yaitu proportional random sampling. Peneliti dan asisten peneliti menentukan siswa yang diteliti untuk masing masing kelas yaitu kelas 4, 5 dan 6 yaitu berdasarkan teknik lotrey dimana gulungan kertas yang telah tertulis nama responden yang keluar dari hasil undian, maka dijadikan sampel.Peneliti dan asisten peneliti pada hari penelitian melakukan koordinasi dengan guru masing-masing kelas yang diteliti yaitu 4, 5 dan 6 untuk membantu mengumpulkan siswa yang terpilih menjadi sampel. Peneliti dan asisten peneliti pada jam yang telah ditentukan melakukan pengumpulan calon responden yang dibantu oleh guru di masing-masing kelas yaitu kelas 4, 5 dan 6.

Peneliti dan asisten penelitimemberikanpenjelasan terhadap calon responden yaitu siswa yang terpilih menjadi sampel yaitu dengan memperkenalkan diri serta memberikan penjelasan tentang tujuan penelitian dana manfaat penelitian.Peneliti dan asisten peneliti meminta calon responden untuk membaca lembar persetujuan, apabila responden mau dilakukan penelitian kemudian di minta untuk menandatangani lembar persetujuan menjadi responden sebagai bukti bahwa sukarela ikut berpartisipasi dalam penelitian.Peneliti dan asisten peneliti membagikan kueioner, selanjutnya peneliti menjelaskan cara pengisiannya yaitu dengan memberikan tanda check $(\sqrt{ })$ pada tempat yang telah disediakan berdasarkan pendapat mereka terkait dengan pernyataan yang digunakan untuk mengukur variabel yang diteliti.Peneliti dan asisten peneliti menarik kembali kuesioner yang sudah terbagi dengan menyediakan kotak sebagai tempat pengumpulan kuesioner dan diperiksa kelengkapan setelah responden selesai mengisi kuesioner, apabila ada jawaban yang kurang lengkap, peneliti atau asisten peneliti meminta responden untuk melengkapinya kembali. Analisis data dilakukan dengan analisis univariat untuk mengetahui gambaran kemampuan interaksi siswa usia 10-12 tahun di SDN Ungaran.

\section{HASIL}

Tabel 1.

Kemampuan Interaksi Sosial Siswa Usia 10-12 Tahun diUngaran $(n=91)$

\begin{tabular}{lcc}
\hline \multicolumn{1}{c}{ Kemampuan InteraksiSosial } & $\mathrm{f}$ & $\%$ \\
\hline Rendah & 6 & 6,6 \\
Sedang & 55 & 60,4 \\
Tinggi & 30 & 33,0 \\
\hline
\end{tabular}

Hasil penelitian menunjukkan bahwa kemampuan interaksi sosial siswa usia 10-12 tahun di Ungaran sebagian besar pada kategori sedang sejumlah $60,4 \%$, tetapi masih terdapat kemampuan interaksi dalam kategori rendah sejumlah6,6\%.

\section{PEMBAHASAN}

Gambaran Kemampuan Interaksi Sosial Siswa Usia 10-12 Tahun di Ungaran

Hasil penelitian menunjukkan kemampuan interaksisosial siswa usia 10-12 tahun di Ungaran kategori rendah sebanyak 6 orang $(6,6 \%)$. Keterampilan sosial didefinisikan sebagai 
perilaku yang dapat diterima secara sosial yang membantu mempromosikan interaksi sosial yang positif (Gresham \& Elliott, 2008). Selama tahuntahun awal, keterampilan sosial dianggap sebagai komponen mendasar dari kesiapan sekolah anakanak, dan secara positif terkait dengan prestasi akademik anakanak di masa mendatang, fungsi sosial dan perilaku, dan bahkan kesehatan fisik dan mental (Blair, 2002; Fiori, Antonucci, \& Cortina, 2006; McClelland, Morrison, \&Holmes, 2000)dalam (Wu, Hu, Fan, Zhang, \& Zhang, 2018). Banyak peneliti berpendapat bahwa usia pra sekolah mungkin merupakan masa kritis bagi anak-anak untuk mengembangka nketerampilan social mereka, karena sebagian besar anak memasuki pra sekolah dan mulai belajar bagaimana mengatur diri mereka untuk berinteraksi secara tepat dengan teman sebaya dan guru (Fabes, Hanish, \& Martin, 2003).

Beberapa penelitian telah menunjukkan bahwa pengembangan keterampilan social cenderung rentan terhadap karakteristik siswa di sekolah (Fabes, Gaertner, \& Popp, 2006). Bahkan, sejauh mana guru dapa tmembangun dan mempertahankan hubungan yang hangat dan responsive dengan anak-anak adalah factor utama dari lingkungan kelas (Hamre \& Pianta, 2007; Zhang \& Nurmi, 2012) dalam (Wu et al., 2018).

Latihan ketrampilan sosial merupakan bentuk terapi ini merupakan metode yang didasarkan prinsip-prinsip sosial dan menggunakan teknik perilaku bermain peran, praktik dan umpan balik guna meningkatkan kemampuan seseorang dalam menyelesaikan masalah (Wakhid, Hamid, \& Daulima, 2013). Kemampuan interaksi social dalam kategori terjadi pada responden yang mempunyai kemampuan interaksi sosial kategori rendah pada indikator persaingan dimana sebagian besar dari mereka menjawab "tidak" pada pernyataan ketika ada masalah saya menganggap diri saya mampu mengatasi sendiri $(65,9 \%)$. Responden menjawab "tidak" pada pernyataan malu berdiskusi dengan orang lain ketika menghadapi masalah karena orang lain sudah memandang sebelah mata terhadap saya $(61,5 \%)$. Responden menjawab "tidak" pada pernyataan percaya diri dalam mengenalkan diri saya ke orang lain $(51,6 \%)$. Latihan ketrampilan sosial diberikan berdasarkan hasil identifikasi masalah yang didapatkan adanya ketidaktahuan dan ketidakmampuan klien dalam membina dan melakukan hubungan social (Wakhid et al., 2013). Adanya latihan ketrampilan social terbukti dapat membantu meningkatkan kemampuan sosial klien yang dapat dilihat pada respon kognitif, sektif, psikomotor, social dan fisik.

Persaingan (competition) merupakan suatu proses sosial, di mana individu atau kelompok-kelompok manusia yang bersaing, mencari keuntungan melalui bidang-bidang kehidupan yang pada suatu masa tertentu menjadi pusat perhatian umum (baik perseorangan maupun kelompok manusia) dengan cara menarik perhatian publik atau dengan mempertajam prasangka yang telah ada, tanpa mempergunakan ancaman atau kekerasan (Sukanto, 2010). Kemampuan interaksisosial siswa usia 10-12 tahun di SDN di Ungaran kategori rendah dimungkinkan karena faktor situasi sosial. Selama masa anak usia sekolah menujuke masa remaja, harga diri didasarkan pada evaluasi diri dalam beberapa konteks yaitu: dalam keluarga, sekolah, pengaturan waktu luang dan kelompok teman sebaya (Harter, 1983) dalam (Seema \& Kumar, 2018).

Pelatihan keterampilan social terbukti sangat efektif dalam meningkatkan harga diri subjek yang diintervensi(Seema \& Kumar, 2018). Selain itu, studi menggunakan langkah-langkah pengamatan akan bermakna untuk secara sistematis memahami perkembangan keterampilan social anak-anak dan hubungan antara keterampilan social dan hubungan guru-anak, yang selanjutnya memberikan saran untuk reformasi kurikulum dan pendidikan guru (Wu et al., 2018). Setelah memasuki pra sekolah dengan atribut yang lebih positif, mereka mungkin memiliki hubungan yang lebih hangat dengan guru pra sekolah mereka yang akan berkontribusi pada serangkaian hasil perkembangan positif (Blankemeyer et al., 2002) dalam (Wu et al., 2018).

\section{SIMPULAN DAN SARAN Simpulan}

Kemampuan interaksisosial siswa usia 10-12 tahun di SDN Ungaran sebagian besar kategori sedang yaitu sebanyak 55 orang $(60,4 \%)$.

\section{Saran}

\section{Bagi Anak Sekolah}

Sebaiknya anak sekolah usia 10-12 tahun meningkatkan kemampuan interaksi sosial mereka diantaranya dengan meningkatkan rasa saling menghormati dan menghargai sehingga proses belajar dapat berjalan dengan baik.

2. Bagi Perawat

Sebaiknya perawat meningkatkan pelayanan bagiusia 10-12 tahun khususnya yang berkaitan dengan peningkatan informasi terkait 
dengan interaksi social misalnya mengadakan kegiatan gathering yang melibatkan siswa sekolah dasar usia 10-12 tahun yang disi dengan interaksi sesama peserta.

3. Bagi Peneliti Selanjutnya

Temuan ini menunjukkan pentingnya peningkatan keterampilan sosial yang harus ditekankan dalam program pendidikan dan intervensi prasekolah. Temuan-temuan dari anak dengan keterampilan sosial dan hubungan guru-anak juga memerlukan perhatian dari pendidikan keluarga.

\section{DAFTAR PUSTAKA}

Hurlock (2007). Psikologi Perkembangan Suatu Pendekatan Sepanjang Rentang Kehidupan. Jakarta: Erlangga.

Notoatmodjo (2007). Ilmu Perilaku Kesehatan. Jakarta : Rineka Cipta.

Pramuwardani, D (2014). Hubungan Gambaran Diri dengan Interaksi Sosial Pada Anak Putri Obesitas di SMA 1 Pecangaan Kabupaten Jepara. KTI. STIKES NWU.

Vincentius (2009). Dinamika Kelompok. Jakarta: PT Bumi Aksara.

Walgito (2008). Pengantar Psikologi Umum. Yogyakarta : Pustaka Pelajar.
Wong (2009). Buku Ajar Keperwatan Pediatric. Jakarta : EGC.

Seema, G. B., \& Kumar, G. V. (2018). Impact of social skills training on self-esteem among male and female adolescent students. Indian Journal of Positive Psychology, 9(1), 147-151.

doi:http://dx.doi.org/10.15614/ijpp.v9i01.1 $\underline{1761}$

Wakhid, A., Hamid, A. Y. S., \& Daulima, N. H. C. (2013). Penerapan Terapi Latihan Ketrampilan Sosial Pada Klien Isolasi Sosial Dan Harga Diri Rendah Dengan Pendekatan Model Hubungan Interpersonal Peplau Di Rs Dr Marzoeki Mahdi Bogor. Jurnal Keperawatan Jiwa, 1(1).

Wu, Z., Hu, B. Y., Fan, X., Zhang, X., \& Zhang, J. (2018). The associations between social skills and teacher-child relationships: $A$ longitudinal study among Chinese preschool children. Children and Youth Services Review, 88, 582-590. doi:https://doi.org/10.1016/j.childyouth.201 $\underline{8.03 .052}$ 